\title{
The Obama Administration and US Relations with the Muslim World
}

On 16 October 2009, the Institute of Global Cultural Studies (IGCS) at Binghamton, jointly with the Association of Muslim Social Scientists of North America (AMSS), sponsored a symposium in Binghamton University's Mandela Hall on "The Obama Administration and US Relations with the Muslim World: Prospects, Progress and Lingering Skepticism.” The presentations addressed Iran's nuclear program, Arab-Israeli relations, Iraq and Afghanistan, Darfur, and studies comparing Obama with Malcolm X and Japan's new prime minister Yukio Haroyama. Inevitably, there was also some debate as to whether Obama's Nobel Peace Prize was legitimately earned or premature.

Ali A. Mazrui (president, AMSS; director, IGCS) used his presidential luncheon address to speak on "Barack Obama: Between the Muslim Crescent and the Star-Spangled Banner." He argued that as a Black president of the world's most powerful country, Obama was both "the most powerful person of color in the history of civilization and the most powerful son of a Muslim since Saladin, the Iraqi who finally defeated the Christian crusaders in Jerusalem on October 2, 1187." This is especially true with regard to military power.

Presenters discussed how to resolve some of the problems in AmericanMuslim relations. Ricardo Rene Laremont (Binghamton University [BU]) proposed Sufism as "a possible peaceful political alternative, especially in North Africa and the Sahel." Muneera Salem-Murdock (Millennium Challenge Corporation, Rabat, Morocco) addressed poverty reduction and economic growth in the Muslim world as a major imperative in mending relations and defusing tensions. Thomas Uthup (United Nations Alliance of Civilizations) recommended building cultural bridges and promoting a genuine dialogue of civilizations.

Patrick Regan (BU), who had visited the Occupied Territories, and M. A. Muqtader Khan (a former AMSS president) discussed and compared the proposed Law of Return for Palestinians with that of the pre-existent Law of Return for any Jew seeking to migrate to Israel. A major gap in the deliberations were the tensions on the Af-Pak border and the Taliban's role in both countries. These issues were to have been addressed by Agha Saeed 
(American Muslim Alliance, California) who, due to illness, was not able to attend.

Except for Darfur, the Obama administration has no coherent SubSaharan Africa policy. Amadu Jacky Kaba (Seton Hall) argued that new sources of petroleum in Africa, rivalry with China, and the threat of terrorism in the Horn of Africa may turn the continent into "the core of US relations with the wider Muslim world." Horace Campbell (Syracuse University) asserted that American relations with the Muslim world included issues of race and emphasized that Obama's vision of a post-racial world could learn from what he called "lessons in Ubuntu healing and transformation from Malcolm X." Henry D'Sonza (Ontario) submitted a paper about Barack Obama's "second one hundred days" and the impact of his domestic preoccupations upon his foreign policy goals. His paper was presented by Patrick Dikirr (Binghamton University).

\section{Obama and the Global Ummah}

During his first one hundred days in office, Obama made no spectacular overture either to Africa or Black America, apart from his expressed concern about Darfur and his interest in solving the problem. Salah Hassan (Cornell University) was critical of Obama's slow response to Darfur. In addition, although his Afro-oriented gestures during this time were so modest, his moves toward the Muslim world were more substantial. His first major television interview for foreign audiences was with the Arabiya television network and addressed to the Arab world. He also addressed the people of Iran on their national day, extending America's hand of goodwill if Iran would "unclench its own fist" toward America. Shireen T. Hunter (Georgetown University) was comprehensive in her treatment of American relations with Iran.

Obama is the first American president since 1979 to call Iran by its official post-revolution name: the Islamic Republic of Iran. His administration also expressed its readiness to engage in direct negotiations with the country concerning its nuclear program and aspirations. The United States has not abandoned its official suspicion that Iran's nuclear motives are ultimately military; however, it is ready to join Europe in direct negotiations with Iran on those issues.

Regan and D'Souza focused on Palestine. Obama appointed George Mitchell, former Senate majority leader and an experienced mediator and negotiator who successfully mediated the Good Friday agreement for Northern Ireland in 1998, as his envoy for the Arab-Israeli conflict. Unlike 
President Bill Clinton, who disproportionately entrusted this dispute to American Jews, Mitchell is of Lebanese-Irish ancestry.

Khan noted the links between the Middle East and South Asia. Obama appointed Richard Holbrook, another very experienced and distinguished mediator, as his special envoy for both Pakistan and Afghanistan. He also invited the presidents of both countries to join him at the White House early in May 2009 for a more fundamental evaluation of their joint policies toward the Taliban and a general struggle against Muslim extremists at large. Laremont argued that the real antidote to Talibanism was Sufism.

Uthup and Kaba looked for bridges of reconciliation. Although the Israeli government that came to power early in 2009 is at best lukewarm about a two-state solution, the Obama administration continues to emphasize that a two-state solution remains official policy. Vice-President Joseph Biden has also stressed this to Jewish American audiences.

In spite of Obama's declared opposition to Israeli settlements, one symposium participant stated that he had to be careful about this issue if he wants a second term. The case of Charles Freeman's nomination to chair the National Intelligence Council, which supervises efforts to generate National Intelligence Estimates, was cited. His 2005 comment that "as long as the United States continues unconditionally to provide subsidies and political protection that make the Israeli occupation and the high-handed and selfdefeating policies it engenders possible, there is little, if any, reason to hope that anything resembling the former peace process can be resurrected,"' along with weak administration support, fatally wounded his nomination.

Obama's policy toward Africa has been less noteworthy than his moves toward the Muslim world. The president might feel inhibited precisely because his father was both an African and a citizen of an African country. Obama was perhaps cautious not to betray either racial nepotism or a manifest bias toward Africa. But he did address Sub-Saharan Africa in a major address from the Ghanaian Parliament during July 2007. His administration, however, remains divided on how to deal with Darfur.

\section{Between Global Africa and the Global Ummah}

The point was raised whether Africa would be better off if Hillary Clinton had been elected. After all, she was such an admirer of African traditions of raising children that her first book carried the African title of It Takes a Village: And Other Lessons Children Teach Us. Although Bill Clinton as president made a major blunder during the lead up to the Rwandan genocide of 1994, his administration demonstrated considerable friendship toward 
Africa in 1998, when he paid the continent the most extensive visit by an incumbent president. Under Obama, the American Navy was authorized to open fire on three Somali "pirates" holding an American captain hostage; Clinton withheld the use of deadly military force on a Mogadishu street even after eight Americans were killed and at least one corpse was dragged provocatively through the streets to the tune of Somali jeers. Instead of retaliating, he ordered the prompt withdrawal of all American troops.

Some attendees predicted that Obama's Africa policy may become more active in a positive sense. While the evidence did make credible the proposition that Africa would be better off if Hillary Clinton had been elected, Obama could become more creatively involved in Africa in the years ahead. On the other hand, examining the Black world as a whole shows that Obama's election has set a remarkable precedent in upward political mobility. The United States is the first white-majority country to elect a man of color to its highest office. Mazrui argued that this precedent could lead to similar events in the United Kingdom, France, and Germany before the end of this twenty-first century and maybe within fifty years in Italy.

Mazrui also made the point that not only is Obama the most powerful Black man in world politics today, but he is also the most powerful man of color in history. He went on to argue that Obama is more powerful than Ramses II, who forced Moses out of Egypt; Ethiopian emperor Menelik II, who defeated the Italians in 1896; and Shaka Zulu of South Africa. But just because he is more powerful than them, this does not necessarily mean that he will be greater than any of them. As commander in chief, Obama commands forces greater than all of the African armies in history added together. Currently, the United States has approximately one thousand military bases overseas. In sheer power, there seems to be little doubt that Obama is in a class by himself among history's Black leaders. But what about his impact upon African Americans? Campbell invoked the name of Malcolm X as a counterpart to Obama.

After some initial hesitation, over 90 percent of African-Americans voted for Obama. But some disenchantment with him surfaced during his first one hundred days because he was perceived as being in denial about the importance of affirmative action and reparations for past injustices. At African-American public meetings to grade his performance, some graded him as low as "C-"; others gave him an "Incomplete." But in the spirit of ubuntu, some of his most important policies were bound to benefit millions of African Americans, although the policies were not specifically focused on them. His aspiration to make health service as affordable and universal as possible is an example, as is his plan to make college more affordable. 
Salem-Murdock addressed poverty, education, and health. With regard to health policies affecting developing countries, Obama has a tough act to follow: former President George W. Bush persuaded Congress to allocate billions of dollars to combat HIV-AIDS in Africa and the Caribbean. Although Muslim Africa was less afflicted by this pandemic, Bush's strategy against HIV-AIDS abroad was arguably his most enlightened policy.

The symposium noted that during the presidential campaign, neither the Republicans nor the Democrats overtly courted Muslims. On the contrary, Obama was sensitive to the erroneous charge that he was a closet Muslim. Muslims were particularly offended when Obama's organizers removed hijab-wearing Muslim women from proximity to him at a rally when cameras were targeting the candidate. Muslims also complained that Obama was prepared to be seen at churches and synagogues, but not at a mosque, even though Bush had visited one. Attention was drawn to his Muslim defenders who felt that the choice was between a Muslim-friendly candidate Obama and a future Muslim-friendly President Obama. Muslim voters could not have both. Obama had to avoid playing the "Muslim card" while he was campaigning. But within his first one hundred days, he stated that he had Muslim relatives and raised the issue of American-Muslim relations to a high level of urgency.

Candidate Obama pledged to end the war in Iraq, support the creation of a sovereign Palestinian state alongside Israel, and combine military action in Afghanistan and Pakistan with considerable American resources for nation-building and economic development. Many of these pledges became explicit after his election. His performance beyond his first year is awaited with baited breath.

\section{Endnotes}

1. Cited by John Mearsheimer, "The Lobby Falters," The London Review of Books, 26 Mar. 2009. John Mearsheimer is the R. Wendell Harrison Distinguished Service Professor of Political Science, University of Chicago.

2. I was a panelist at one such meeting sponsored by the Institute of the Black World 21st Century and New York Avenue Presbyterian Church on 24 Apr. 2009. Other panelists included Congressman John Conyers (D-MI).

\section{Appendix}

Co-Chairs: David Cingranelli (BU) and Seifudein Adem (associate director, IGCS, BU). Chairs of Individual Panels: David Cingranelli, Seifudein Adem, Olga Shvetsova (BU), Nkiru Nzegwu (BU), and Abubaker al Shingieti 
(International Institute of Islamic Thought). Panelists and Paper Presenters: Panel 1: Henry D'Souza (Ontario), Patrick Dikirr (BU), M. A. Muqtedar Khan (University of Delaware), and Patrick Regan (BU). Panel 2: Amadu Jacky Kaba (Seton Hall University), Seifudein Adem, and Thomas Uthup (United Nations Alliance of Civilizations). Panel 3: Ricardo Rene Laremont (BU), Shireen Hunter (Georgetown University), and Horace G. Campbell (Syracuse University). Panel 4: Salah M. Hassan (Cornell University) and Muneera Salem-Murdock (Millennium Challenge Corporation, Rabat, Morocco). Conference Coordinators: Layla Sein (AMSS), Seifudein Adem, Ravenna Narizzano (IGCS), and Barbara Tierno (IGCS).

Ali Mazrui

Director, Institute of Global Cultural Studies Binghamton University, New York 